DOI: https://doi.org/10.34069/AI/2021.44.08.22

How to Cite:

Pavlyuk, O., Parasiuk, N., Dutko, A., Parasiuk, V., \& Stasiv, O. (2021). Protection of patent law objects, created by artificial intelligence (AI) technologies. Amazonia Investiga, 10(44), 230-240. https://doi.org/10.34069/AI/2021.44.08.22

\title{
Protection of patent law objects, created by artificial intelligence (AI) technologies
}

\section{Охороноздатність об'сктів патентного права, створених технологіями штучного інтелекту}

Received: August 1, 2021

\begin{abstract}
The aim of the article is to solve the scientific problem of outlining the issue of protection of patent law objects created using artificial intelligence technologies, and to establish whether it is possible to recognize artificial intelligence technologies as inventor at the present stage of development of legal systems. Philosophical, comparative-legal and systemstructural methods were used in the research process. Based on the analysis of the European Patent Convention, the main generally accepted conditions of patentability of the invention are determined: novelty, inventive step, industrial applicability. It has been established that inventions created by artificial intelligence technologies will meet such criteria provided that certain requirements are met. In the context of the study, the case of the invention of artificial intelligence «DABUS» is analyzed and the results of its consideration in the European Patent Organization, the United Kingdom and the United States are summarized. In particular, it
\end{abstract}

Accepted: September 15, 2021

$\begin{array}{r}\text { Written by: } \\ \text { Olha Pavlyuk }^{87}\end{array}$
https://orcid.org/0000-0002-6165-4767
Nataliia Parasiuk ${ }^{88}$
https://orcid.org/0000-0002-7489-9181
Alona Dutko ${ }^{89}$
https://orcid.org/0000-0002-5062-6947
Vasyl Parasiuk ${ }^{90}$
https://orcid.org/0000-0002-8195-7597
Oksana Stasiv $^{91}$
https://orcid.org/0000-0002-4846-7035

Анотація

Метою статті $є$ вирішення наукового завдання щодо окреслення проблематики охороноздатності об'єктів патентного права, створених за допомогою технологій штучного інтелекту, та встановлення можливості визнання технологій штучного інтелекту винахідниками на сучасному етапі розвитку правових систем. В процесі дослідження використано філософський, порівняльноправовий та системно-структурний методи. На основі аналізу Європейської патентної конвенції визначено основні загальновизнані умови патентоздатності винаходу: новизна, винахідницький рівень, промислова придатність. Встановлено, що винаходи, створені технологіями штучного інтелекту, відповідатимуть таким критеріям за умови дотримання певних вимог. В контексті дослідження проаналізовано справу щодо винахідництва штучного інтелекту «DABUS» та підсумовано результати іiі розгляду у Європейській патентній організації,

\footnotetext{
${ }^{87}$ Postgraduate student of the Civil Law Disciplines Department, Institute of Law, Lviv State University of Internal Affairs, Lviv, Ukraine.

${ }^{88}$ Candidate of Law, Associate Professor, Associate Professor of the Criminal Law Department, Institute of Law, Lviv State University of Internal Affairs, Lviv, Ukraine.

${ }^{89}$ Candidate of Law, Associate Professor, Associate Professor of the Civil Law Disciplines Department, Institute of Law, Lviv State University of Internal Affairs, Lviv, Ukraine.

${ }^{90}$ Candidate of Law, Associate Professor, Associate Professor of the Theory of Law, Constitutional and Private Law Department, Institute of Specialist Training for National Police Units, Lviv State University of Internal Affairs, Lviv, Ukraine.

${ }^{11}$ Candidate of Law, Associate Professor, Associate Professor of the Social Law Department, Faculty of Law, Ivan Franko National University of Lviv, Lviv, Ukraine.
} 


\section{$\frac{\text { AMAZONIA }}{\text { Drvestiga }}$}

has been established that artificial intelligence technologies are currently not considered as inventors in either the Romano-Germanic or Anglo-Saxon legal systems.

Key words: patent law, invention, patentability, human inventor, artificial intelligence (AI) inventor.

\section{Introduction}

The rapid development of artificial intelligence (AI) has a significant impact on the economy and society as a whole. Such innovations affect both production and the industrial characteristics of a wide range of goods and services, which is important for productivity, employment and competition. However, it should be understood that artificial intelligence can have consequences that can be equally profound for all institutions of modern society and at the same time have a decisive impact on certain specific institutions, including the legal regulation of objects of patent law created by artificial intelligence technologies.

Patent law has traditionally developed on the basis of the concept of «human inventor». At the same time, the emergence of such a concept as «inventor-artificial intelligence» raises a number of new questions to which the modern patent system may not have simple answers and solutions. For example, it is unclear whether artificial intelligence algorithms (AIs) should be subject to patent protection, or whether the widespread use of AI inventions would require a reassessment of basic patent concepts, such as the inventive step. There is no consensus on whether technology can be considered an inventor. Who would own a patent if AI technology created an invention with little or no human intervention?

Thus, the purpose of this study will be to determine whether it is possible in the current legal field to recognize artificial intelligence as an inventor.

Achieving this goal will help determine whether patent law is consistent with today's realities and the rapid development of technology.

\section{Literature review}

Given that in Ukrainian science there are almost no publications of domestic authors on the subject of this study, the scientific and theoretical basis was the work of such authors as Abbott R.,
Великобританії та США. Зокрема, встановлено, що технології штучного інтелекту на теперішній час не вважаються винахідниками ні в романо-германській, ні в англо-саксонській системах права.

Ключові слова: патентне право, винахід, патентоздатність, винахідник-людина, винахідник-штучний інтелект.

Blok P., Fraser E., Hattenbach B., Glucof J., Mclaughlin M., Tull S., Vertinsky L., Sánchez E. G., García L. S., Gargallo M. M., Rodríguez E. G., Arias D. D., Manrique R., Giraldo F. and others. The content of the position of these scientists on the issue to be considered in this article will be set out in the main text of the study. However, we consider it appropriate to mention some of them.

For example, Abbott's position is that computers have been "autonomously" producing patentable results for at least the last two decades and proves that such inventions meet the criteria of patentability. Abbott even argues that computational innovations can gradually lead to the complete replacement of the notion of «expert in the relevant field of technology» by the notion of «skilled computer», resulting in «everything would be obvious» for a superintelligent machine (Abbott, 2016).

In opinion of Sánchez E. G., artificial intelligence is widely used in reports, conferences and other events of an essentially informative nature, but it lacks a minimum of safe contours that need to be limited when it comes to analyzing the legal forms that can be used for their protection. Author mentions that $\mathrm{AI}$ and its' technical nature should be analyzed considering the EPO Board of Appeal Decisions and the EPO Guidelines, which do not maintain the same criteria in all cases. Sánchez E. G. also defends the cumulative nature of this protection system with which it derives from copyright and trade secrets legislation (Gallego Sánchez, 2019). Vertinsky L. notes that, today, artificial intelligence technologies, such as artificial neural networks, are able to study and find solutions to certain problems with little or no human involvement and there are cases when technologies generate appropriate inventive solutions with a significant degree of autonomy and are no longer just tools that have helped people in this (Vertinsky, 2017). 
García L. S. stated that, today, there are already patentable inventions created by a phenomenon known as Artificial Intelligence. In his scientific research he introduced a new notion of «Artificial Intelligent Agent» (AIA), which, on his opinion, allowing to cover all the branches of AI capable of generating inventions autonomously. The AIAs would become true subjects of rights and obligations, an option that, in his opinion, would need to be nuanced, having to submit the exercise of the powers recognized by this "legal personality". He also proposed a specific regime for inventions created by AIAs. In his opinion, and given the character of subordination to a predicable human and, above all, expected from AIAs, one could to draw up a regime of ownership of the inventions generated by these entities establishing a parallel with those achieved in the framework of an employment or service relationship - labor inventions (Sánchez García, 2018).

Fraser E. indicates that the increasing use of AI may require a complete rethinking of the existing standard of inventive step in the long run, given that computers have extensive prior art knowledge - potentially far beyond anyone's knowledge (Fraser, 2016).

Gargallo M. M. notes that the use of artificial intelligence systems to generate inventions determines the need to consider their role in the inventive process. Patent legislation links the condition of inventor to the natural person, starting from the conception of that an invention is the fruit of human ingenuity. Author also emphasizes that, only when the human contribution is accessory, because the artificial system acts in a fully autonomous, the adaptation of the patent system should be considered so that such inventions can also take advantage of the incentives for technical progress that patent law provides (María del Mar Maroño Gargallo, 2020).

According to the Blok P., European Patent Convention does not explicitly exclude the patentability of inventions generated by AI systems, and the way in which the invention was created does not matter (Blok, 2017).

Rodríguez E. G., Arias D. D., Manrique R., Giraldo F. state that, strengthen the capacities of industrial property offices in the field of AI is a fundamental challenge to overcome the difficulties associated with the low number of professionals with the required training and with the volume of records that must be analyze. In this context, both World intellectual property organization and competent national offices have understood that the use of artificial intelligence technologies and developments in the management of industrial property is a powerful and useful tool to assist in their functions missionaries. Such AI systems are of course dependent on data (and algorithms) and in the world of IP an access policy is widely accepted open to information related to patent applications, brands and designs (García Rodríguez, Duque Arias, Manrique, Giraldo, 2020).

All the above researchers have tried to solve some problems related to the patentability of inventions that have been created by artificial intelligence technologies. Despite the various subjects of their research, they all, in one way or another, concluded that although at the moment, no legal system has expressly provided for a specific regulation for inventions generated by AI, artificial intelligence is able to create inventions that will meet the criteria of patentability and may, as a consequence, be recognized as an inventor.

Some legal problems of using artificial intelligence technologies are considered in the works of O. A. Baranov, O.E. Radutny, E.O. Kharitonova, O.I. Kharitonova and others.

At the same time, the research of domestic scientists ignores the problematic for the modern world issues regarding the use of artificial intelligence technologies in the field of patent law, in particular, in the creation of inventions, which determines the need and relevance of this study.

\section{Methodology}

The methodological basis of the study is a system of philosophical, general and special methods of scientific knowledge, characteristic of legal science - philosophical, comparative law, system-structural methods.

The above methods were used as follows: philosophical method - used in the review of the state and methods of using artificial intelligence technologies in the field of patent law, helped to identify the main generally accepted features of the patentability of the invention; comparative legal method - it was used to determine the features of international legal regulation of the legal status of patent law objects created by artificial intelligence technologies, on the example of European Union, US and UK legislation, in particular, generalize and compare 


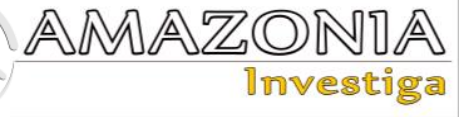

the results of DABUS case in these countries; system method - based on the study and the collected data system, it helped to establish the answer to the question of the possibility of recognizing artificial intelligence as an inventor at this stage of development of legal systems.

The application of the system of these methods is conditioned by the specifics of the raised problem and allowed to ensure the reliability of the obtained results, the correctness of the formulated conclusions, the solution of the outlined tasks and the achievement of the set goal.

\section{Results and discussion}

Machines and computers have been used for a long time as tools to create a variety of patentable inventions in fields such as chemistry and biotechnology (Hattenbach and Glucoft, 2015).

Today, artificial intelligence technologies, such as artificial neural networks, are able to study and find solutions to certain problems with little or no human involvement. So, there are cases when technologies generate appropriate inventive solutions with a significant degree of autonomy and are no longer just tools that have helped people in this (Vertinsky, 2017).

Thus, the participation of the computer in the inventive process can be conceptualized in the process of producing a certain object or creating a certain good. This process is gradually moving from man-made inventions to inventions created using technology, and finally to computer inventions (suggesting that the importance of the human role in this process is gradually diminishing or disappearing altogether) (McLaughlin, 2018).

Not surprisingly, it is the last stage of this process that is particularly controversial in the context of patent law.

Abbott argues that computers have been «autonomously» producing patentable results for at least the last two decades (Abbott, 2016).

Before addressing the invention of AI technology, the interaction between AI inventions, existing patent law rules, and basic patentability requirements for inventions, such as novelty, inventive step, and industrial applicability, should be considered.

It is known that patents are issued as part of a socalled «patent agreement» - a time-limited monopoly granted to individuals in exchange for the disclosure of new inventions in the public sphere (and, ultimately, providing them with open access). The rationale for this is that, although the patent owner receives a set of temporary exclusive rights, the technical information disclosed by the patent owner can be used by competitors and the general public after 20 years. Patents are granted exclusively for inventions that have a relevant subject, are new, include the inventive step and can be applied industrially (European Patent Convention, 1973). The European Patent Convention (hereinafter EPC) provides the appropriate legal basis for the grant of European patents. With regard to the subject matter, the EPC does not attribute patentability to, inter alia, discoveries, mathematical methods, mental actions and computer programs, but «only to the extent that a european patent application or a european patent relates to an object or activity as such» (European Patent Convention, 1973).

For the purposes of this analysis, a distinction should be made between the patentability of the AI system itself and its works. First, a typical AI algorithm - such as a neural network - is likely to be considered a mere mathematical method or mental act and is therefore not in itself patentable due to its lack of technical effect.

At the same time, the European Patent Organization (hereinafter - EPO) has issued specific guidelines on artificial intelligence and machine learning, recognizing that, for example, the use of a neural network to detect irregular heartbeat would be technically necessary to qualify as a patentable invention (in contrast to the system for classifying text solely in terms of its literal content, which is unlikely to meet this criterion) (EPO Guidelines for Examination, 2021). The specificity of patent applications is likely to be key in these circumstances; nonspecific, vague, or applications with significantly exaggerated content obviously fail (Borella, 2018).

On the other hand, limiting a patent application to a specific technical purpose may be crucial for recognizing the existence of an appropriate technical level recognition according to the invention (Hashiguchi, 2017). Accordingly, inventions that are based on machine learning or AI designed to solve a particular problem, often without limiting the solution to a particular algorithm, may be considered patentable.

Second, the EPC does not explicitly exclude the patentability of inventions generated by AI 
systems, and the way in which the invention was created does not matter (Blok, 2017).

Moreover, Article 27 of the Agreement on TradeRelated Aspects of Intellectual Property Rights and Article 52 of the EPC state that patents must be granted without discrimination in the field of technology (EPO Case T-1173/97, 1998). Thus, it can be argued that inventions should be considered patentable even if they are generated autonomously by AI.

The next step in the study is to establish the main criteria for granting legal protection to inventions and whether they can be applied to inventions created by artificial intelligence technologies.

It is necessary to begin with novelty.

In order to be patentable, an invention must be «new». The condition of novelty is met when the invention is not part of the «state of the art», a concept that includes all materials available to the public anywhere in the world before the date of priority (European Patent Convention, 1973). However, the key issue here is the risk that AI technology can make it significantly more difficult for the applicant to establish novelty in general. In fact, AI could dramatically expand the previous level of creativity - which is fundamental to the assessment of novelty: «where thinking machines ... expand what people understand, the concept of the prior art can become much broader ... complicating the establishment of novelty ... The concept accessibility and use may need to be reconsidered, for example, where thinking machines generate vast amounts of discoveries and make those discoveries that are easily accessible to machines but incomprehensible to humans» (Vertinsky, 2017).

Applications created by AI (for example, applications from the French company Cloem, which uses existing language processing technologies to help patent applicants) can also be specifically created to saturate the technical space around already patented inventions to prevent patentee's competitors from obtaining patents for improvements in the same field (Hattenbach, Glucoft, 2015).

However, not all information published on the Internet is able to destroy the novelty of the invention. The physical availability of such information is not critical «if the computergenerated texts were not actually instructive to the educated reader» (Fraser, 2016).
The next criterion is the inventive step. In order to be patentable, an invention must meet the inventive step requirement (Article 52 (1) EPC). This condition is met when (given the state of the art) the invention would not be obvious to a «specialist in a particular field» (European Patent Convention, 1973).

A specialist in a particular field is understood as «a qualified specialist in the relevant field of technology who has average knowledge and abilities». Therefore, patents cannot be granted for inventions that are within the knowledge of the average expert in the field, who, according to Blok (2017), is «generally considered» (albeit implicitly) human.

The use of terms such as «person» and «specialist» adds additional importance to this argument.

Given the (potentially) high level of intelligence of 21 st century technologies, the result of its activities - the invention - in many cases would correspond to the required inventive step, which is recognized as a threshold. For example, some of Watson's work (an IBM-designed computer capable of answering questions, asked in colloquial language) surprised even its developers - it's «encouraging» in terms of artificial intelligence ingenuity, given that unexpected results are sometimes acceptable when experts assess the non-obviousness of the invention (Abbott, 2016).

Conversely, certain applications that have been mechanically generated by AI can be considered obvious. For example, the aforementioned company Cloem uses software for linguistic manipulation, which simply adds or removes sentences. He relies on a «rough calculation» to compile texts for thousands of statements that may cover new inventions.

However, many of these claims would be «the result of a relatively small adjustment, and these minor modifications that work in predictable ways would be considered obvious» (Hattenbach and Glucoft, 2015).

Most importantly, the increasing use of AI may require a complete rethinking of the existing standard of inventive step in the long run, given that computers have extensive prior art knowledge - potentially far beyond anyone's knowledge.

The spread of AI may necessitate raising the level of patentability and making changes to the 


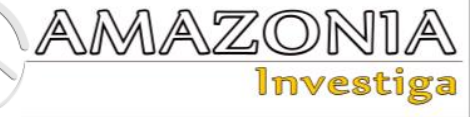

existing concept of «specialist in a particular field», including a person «equipped with $\mathrm{AI} »$, raising the ability of a conventional person to the capabilities of a complex machine (Tull, Miller, 2018).

Abbott even argues that computational innovations can gradually lead to the complete replacement of the notion of «expert in the relevant field of technology» by the notion of «skilled computer», resulting in «everything would be obvious» for a superintelligent machine (Abbott, 2016).

According to Abbott, as machines-inventors continue to improve, this will increasingly raise the bar of patentability, which over time makes innovation obvious. The end of the obvious means the end of patents, at least as we know them now (Abbott, 2019).

Therefore, an overly expansive approach to the obvious would mean that very few things could receive patent protection.

Moreover, while more stringent patent procedures are generally welcomed (especially since patent offices often criticize excessive generosity), a patent system in which the basic level of inventive step includes a «skilled computer» is not without its problems. Inspectors and judges would have to think like a machine and consider a level of technology that may be within the reach of computers, but not people, which is practically impossible.

As for the requirement of industrial applicability of the invention, this requirement is met by providing that the invention can be created or used in any field (European Patent Convention, 1973). Although this is a basic requirement, the inventions created by AI do not raise any new issues in this regard. For example, the bristle design of the Oral-B toothbrush invented by Thaler's Creativity Machine would probably meet this requirement.

The disclosure requirement stimulates innovation: it prevents unnecessary duplication of research, allows innovation to continue by informing patent owners about the limits of the patented invention, and benefits the general public by ensuring the dissemination of new technology.

From the point of view of the inventions created by AI, it is often difficult to describe how the algorithm actually works. As Rich explains, «machine learning tends to create such complex models that they turn into 'black boxes', where even the original programmers of the algorithm have little idea how and why the created model provides accurate predictions» (Rich, 2016).

Consider an example of an artificial intelligence system that learns from a very specific set of data, as a result of which the configuration is not fully known or cannot be duplicated by others. The key problem is that if the invention cannot be reproduced, it will not be considered sufficiently disclosed.

On this basis, Frueh argues that «the requirement of patent law to disclose information about an invention ... is under attack by AI, and this may adversely affect the patent system as a whole, especially its legitimacy, which is based on a «quid pro quo-bargain» - the so-called «contract theory» (Frueh, 2019).

Having determined the main criteria for the patentability of inventions, and that inventions created by artificial intelligence technologies meet them under certain conditions, it is necessary to investigate the answer to the main problem of this study - whether artificial intelligence is recognized by the inventor in the current legal system.

A review of the well-known DABUS case, the subject of which was the issue of invention in the context of AI, will help to resolve this problem. In January 2020, the EPO published a document setting out its grounds for refusing two patent applications filed by Stephen Thaler's legal representatives under the Artificial Intelligence Project, calling the machine (DABUS) an inventor. The Artificial Intelligence Project team was led by Ryan Abbott (an academician at the University of Surrey), who has recognized intellectual property rights to autonomously created artificial intelligence objects. The project team acknowledged that although in most cases the AI system acts only as a «tool», there are cases where the act of invention can be functionally automated and performed by a machine. They point out that there is no need to protect the AI's right to own the invention, given that the machine does not have any legal status and cannot be the owner. They argue that it is the AI owner who should have the right to own the results created by the AI.

Thaler filed two separate applications with the EPO (in addition to the applications filed with the U.S. Patent and Trademark Office, the UK Intellectual Property Office and the Israeli Patent Office), according to which DABUS was 
identified as the inventor. The first application was submitted for a plastic beverage container (EP18275163); another application concerned a flashing beacon intended for use in search and rescue missions (EP18275174).

According to the applicant, the machine «discovered the novelty of its own idea earlier than an individual did» (EPO, 2020). For simplicity of the analysis it is necessary to stop on the first application mentioned above (arguments are identical in both decisions).

When the applications were submitted to the EPO, the applicant left the place where the data on the inventor should have been indicated blank. Thaler was allowed to rectify this because the application did not comply with Article 81 and Rule 19 (1) of the EPC, which states that a European patent application must identify the inventor. He later identified «DABUS» as an inventor, describing it as «a type of connective artificial intelligence» (EPO, 2020). Thaler further argued that Rule 19 (1) of the EPC did not require the inventor to be a human being and that the actual purpose of the provision was to correctly identify the inventor. He also argued that, given that the AI system had created the invention on its own, calling someone else an inventor (even oneself) would be a violation of important principles of patent law; moreover, he argued that «an inaccurate reference to an individual as an inventor would mislead the public» (EPO, 2020).

Thaler further argued that the designation of DABUS as the inventor was in line with the main objectives of the patent system, namely «to stimulate the disclosure, commercialization and development of inventions» (EPO, 2020).

The need for the inventor's details to include both his name and surname (argued below) will lead to unfair treatment of people of the same name. Finally, Thaler stated that he had obtained the right to a patent from DABUS as his «successor». He pointed out that, as the owner of the machine, he has the right to own any intellectual property rights created by the $\mathrm{AI}$.

The EPO rejected both applications on the grounds that no one was identified in the application as an inventor, contrary to the provisions of Article 81 and Rule 19 (1) of the EPC. The organization noted that according to Rule 19 (1) of the EPC, the designation must include a surname, name and address; just giving the machine a name (which is the case here) is not enough.
Moreover, the European Patent Organization noted that 1) the section of the EPC «Travaux Préparatoires» constantly identifies an individual as inventor; 2) the interpretation of the term «inventor» through the concept of an individual is an «international standard»; 3) the concept of «human inventor» is recognized by various national courts, most members of the EPC, major patent offices, including Japan, the United States and China; 4) the patent laws of some Contracting States to the EPC clearly define the «inventor» as the natural person who created the invention; and 5) no national legislation has yet recognized artificial intelligence as an inventor (EPO, 2020).

Finally, the EPO rejected the argument that the applicant was the «employer» of DABUS - and therefore the successor under Article 60 (1) of the EPC. The reason for this was that AI systems and machines, as a rule, could neither be workers nor transfer any rights to a person due to lack of legal personality (EPO, 2020).

The UK Intellectual Property Office (UKIPO) issued a similar decision on DABUS in December 2019, which was later upheld by the High Court of Appeal of England and Wales.

The key issues in the UK Intellectual Property Office were: 1) whether a non-human inventor could be considered an inventor under the UK Patent Act 1977; and 2) whether Mr Thaler (the applicant) was entitled to apply for a patent (in favor of DABUS) only because he was the owner of the AI. The UK Intellectual Property Office, citing $\$ 7$ (on the right to apply for a patent) and $\S 13$ of the Act (which, inter alia, required the applicant to explain how he obtained the patent in cases where he was not an inventor), answered negatively to both questions. In response to the first question, the UK Intellectual Property Office acknowledged that DABUS had created the inventions (the Office's practice is to accept the inventor's designation as such), but stated that the machine could not be called an inventor because it was not an individual.

Moreover, the United Kingdom Intellectual Property Office argued (hereinafter - UKIPO) that, although there is no directly relevant case law on this issue, at the same time there is a «clear expectation that the inventor and the person for the purposes of 7 and 13 respectively - it's one and the same, namely an individual - a person, not a machine endowed with $\mathrm{AI} »(\mathrm{UK}$ Intellectual Property Office, 2019). 


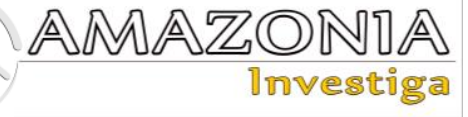

The Office also noted that such arguments of the applicant essentially led to an interpretation of the law contrary to the purpose for which it was aimed, especially in the absence of any instructions from the legislature and the judiciary that the term «person» could mean anything else than an individual.

Responding to the second question (could Thaler have applied for a patent in favor of DABUS because he is the owner of AI), UKIPO stated that since DABUS is a machine that cannot own intellectual property due to its lack of legal status, it «has no right to its inventions and cannot enter into any agreement to transfer its right to apply for a patent to another person» (UK Intellectual Property Office, 2019).

Most importantly, while the UKIPO's position on the above issues is not unexpected, the Office acknowledged that as inventions based on artificial intelligence are likely to become much more widespread in the future, further discussions on how the patent system must cope with such challenges should take place.

Recognizing that the existing legal system «does not properly regulate the legal status of such inventions, and it was never foreseen that this would be necessary», the UKIPO concluded that any changes to the law should be seen in the context of this debate, as opposed to arbitrary incorporation into existing legislation (UK Intellectual Property Office, 2019).

The High Court of Appeal of England and Wales upheld the decision of the UKIPO in September 2020.

In its decision, The High Court of Appeal placed considerable emphasis on the wording of the Law and refused to depart from its literal interpretation. The Court has made it clear that the current law does not provide for inventions created by artificial intelligence, and any changes in this position require action at the legislative level. Parliament could theoretically amend sections 7 and 13 of the Act to include AI systems as inventors, and, for example, automatically grant the owner of a machine any patents created by AI. However, ideally, any such reform should be discussed through a harm-benefit analysis through open consultations to assess the impact in this area.

Following the High Court ruling, Professor Ryan Abbott (who coordinates DABUS applications) stated that such an approach did not protect an increasing number of inventions that lacked a human inventor (Nurton, 2020).

Moreover, he stressed that it allows people to take credit for work they have not done, thereby devaluing people's invention and misleading the public (Nurton, 2020).

Following the decisions of the EPO and UKIPO, the U.S. Patent and Trademark Office came to a similar conclusion regarding a parallel application filed by Thaler in the United States.

In this case, Thaler is listed as the successor and the applicant in the application. «DABUS» was marked as the name of the inventor, and «Invention created by artificial intelligence» as a surname. The U.S. Patent and Trademark Office has stressed that various U.S. patent regulations consistently refer to «inventors» as individuals; e.g. 35 USC $\S 101$ uses the phrase «[who] creates or discovers», and 35 USC $\$ 115$ uses terms such as «self», «self», «individual» and «person». Based on relevant case law, the U.S. Patent and Trademark Office has also argued that it is clear that the concept of an invention (the «cornerstone of invention») is based on its creation by an individual (USPTO, 2019).

Finally, the Office rejected Thaler's argument that recognizing the machine as an inventor would encourage the creation of artificial intelligence systems-inventor and concluded that «granting a patent ... for an invention covering a machine does not mean that the machine can be included as inventor to another patent application (a camera patent allows the camera to own copyright) ... the machine cannot be an inventor under patent law» (USPTO, 2019).

Following a decision on August 6, 2020, Thaler Law Group filed a lawsuit against the U.S. Patent and Trademark Office in the Eastern District Court of Virginia.

In Thaler v. Iancu, group argues that the Bureau should follow the report of the National Patent Planning Commission of 1943, which states that «patentability is determined objectively by the nature of the contribution to the development of creativity, and not subjectively by the nature of the process by which, perhaps, the invention was created», thus opening the way to the invention of AI.

The team explained its reasoning as follows: «We want to innovate. AI has been used to generate innovation for decades, and $\mathrm{AI}$ is getting better and better at doing these things, and 
people aren't ... The law doesn't clearly define whether you can have a patent if AI does that job, but if you can't protect inventions created by artificial intelligence, you will be deprived of the opportunity to use them» (Thaler v Iancu et al, 2020).

The current case of the invention of artificial intelligence in the case of Thaler v. Iancu received another turn on April 6, when the judge of the US District Court Leonie Brinkem of the Eastern District of Virginia pointed out that artificial intelligence systems can not be listed as inventors in US patent applications.

At a brief hearing in the case, Judge Brinkem stated that Plaintiff Thaler was waging a «difficult battle ... because the legislative language [of the Patent Law] is so crystal clear that «the inventor» must be an «individual» and not a machine. Judge Brinkem further stated that the work of the legislature, not the courts, is to address such issues, given the rapid development of technology; «Courts are not legislatures ... and I think that, after all, what you are asking this court to do is adopt new legislation».

As of May 2021, this case has not yet been considered by the district court.

\section{Conclusions}

Based on this study, it can be argued that artificial intelligence systems are now able to generate inventive results autonomously. However, because patent law has traditionally been designed with the human inventor in mind, many of its basic principles do not conform to the idea of an invention created by artificial intelligence technology.

It is established that the main internationally recognized criteria of patentability are novelty, inventive step, industrial applicability. It is determined that inventions created by artificial intelligence can meet such criteria under certain conditions, which were discussed above.

Based on the evaluation of the results of the DABUS case in various legal systems, it has been established that AI systems cannot currently be called inventors in either Europe or the United States. Is this approach optimal? There is no scientific consensus.

Instead, there is a situation where patent applicants may now not disclose the role played by the $\mathrm{AI}$ in the development of the invention (and instead call themselves inventors) in order to avoid problems in the patent offices on the grounds mentioned above. In other words, the existing legal system, in fact, authorizes lies in cases where a person actually had little or no role in the inventive process. Instead of indirectly encouraging dishonesty, patent offices should introduce a requirement for transparency and disclose the role of technology in the process of invention.

Because patent applications where the inventorartificial intelligence is unlikely to succeed, there is a risk that inventors will instead rely on trade secrets, keeping the invention secret and effectively undermining the basic rationale of the «patent agreement» (where both the inventor and society receive benefit from the disclosure and commercialization of the invention).

It is important to emphasize that not everyone agrees that inventions created using artificial intelligence technologies should be subject to patent protection. One possible alternative is an approach in which inventions created by AI automatically enter the public domain and are freely available to the general public. This may be justified on the grounds that, for example, the proliferation of machines-inventors could lead to an excessive number of patents being issued in the future, concentrated in the hands of several large corporations. However, such an approach may encourage the unfairness of patent applications, which will obscure the evidence for the invention of AI.

Based on the above, it is possible to draw a conclusion that within the current legal field and taking into account the traditional approach to understanding inventive activity, to resolve issues with legal protection of potentially patentable results autonomously created by artificial intelligence technologies as inventions is currently not possible. This situation is typical not only for Ukraine but also for many other countries, and requires further study and appropriate solutions, including by changing the legal structures established by law, which is increasingly being talked about by experts.

It is obvious that the current legal mechanisms in most countries do not take into account the current level of development of artificial intelligence technologies and do not allow to protect potentially protective solutions in the scientific and technical field created by artificial intelligence systems. Of course, this state of affairs cannot meet the main goal of the patent system - to ensure the creation of new products and the development of advanced technologies in 


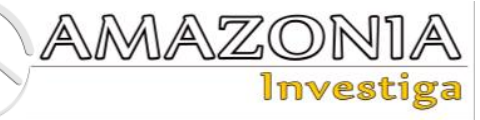

any field in the interests of society as a whole. The optimal solution in this regard is the development of legislation.

Intellectual property law needs to undergo significant changes with the development of new technologies, but there is no urgent need to radically change the entire system and principles of this branch of law in order to ensure the recognition of the legal personality of artificial intelligence. In addition, given the current level of software and mathematical support for the development of artificial intelligence, there is also no urgent need (at least now and in the foreseeable future) to recognize artificial intelligence as a full-fledged (full-fledged, legal entity) subject of copyright and patent rights, intellectual property rights in general.

\section{Bibliographic references}

Abbott, R. (2016). I Think, Therefore I Invent: Creative Computers and the Future of Patent Law. Boston College Law Review, 57(4), 1079-1126.

Abbott, R. (2019, May 28). Everything is obvious. Intellectual Property Watch. Recovered from https://www.ipwatch.org/2019/03/25/everything-isobvious/.

Blok, P. (2017). The inventor's new tool: artificial intelligence - how does it fit in the European patent system? European intellectual property review, 39(2). 69-73.

Borella, M. (2018, November 25). How to draft patent claims for machine learning inventions. Patentdocs. Recovered from https://www.patentdocs.org/2018/11/how-todraft-patent-claims-for-machine-learninginventions.html.

García Rodríguez, E., Duque Arias, D., Manrique, R,. \& Giraldo, F. (2020). El Uso de Sistemas Inteligentes (IA) en el Registro de Propiedad Industrial. Revista La Propiedad Inmaterial, 30, 295-326. Retrieved from 10.18601/16571959.n30.11

EPO. (1998). Case T-1173/97 Computer Program Product/IBM, Technical Board of Appeal. Recovered from https://www.epo.org/law-practice/case-lawappeals/pdf/t971173ex1.pdf.

EPO. (2020). Grounds for the EPO decision of 27 January 2020 on EP 18275 163. Recovered from

https://register.epo.org/application?documen tId=E4B63SD62191498\&number=EP18275 $163 \& \operatorname{lng}=$ en $\&$ npl=false.
EPO. (2021). Guidelines for Examination in the European Patent Office. Recovered from https://documents.epo.org/projects/babylon/e ponet.nsf/0/C4B20952A0A7EF6BC125868 B002A5C61/\$File/epo_guidelines_for_exam ination_2021_hyperlinked_en.pdf.

Fraser, E. (2016). Computers as Inventors Legal and Policy Implications of Artificial Intelligence on Patent Law. SCRIPTed, 13(3), 305-333.

Frueh, A. (2019). Transparency in the Patent System - Artificial Intelligence and the Disclosure Requirement. Žaneta Pacud and Rafał Sikorski, (3), 1-15.

García, L. S (2018). Invenciones generadas por inteligencia artificial y sus implicaciones para el derecho de patentes. Informática y Derecho: Revista Iberoamericana de Derecho Informático (segunda época), (5), 49-84.

Gargallo, M. D. M. M. (2020). El concepto de inventor en el derecho de patentes y los sistemas de inteligencia artificial. Cuadernos de derecho transnacional, 12(2), 510-526.

Hashiguchi, M. (2017). The Global Artificial Intelligence Revolution Challenges Patent Eligibility Laws. Journal of Business \& Technology Law, 13(1), 1-36.

Hattenbach, B., \& Glucof, J. (2015). Patents in an Era of Infinite Monkeys and Artificial Intelligence. Stanford Technology Law Review, 32, 33-51.

Mclaughlin, M. (2018). Computer-Generated Inventions. American University Washington College of Law, 39, 1-32.

Nurton, J. (2020, September 24). UK judge upholds refusal of DABUS patents. Ipwatchdog. Recovered from https://www.ipwatchdog.com/2020/09/24/uk -judge-upholds-refusal-dabus patents/id=125584/.

Rich, M. (2016). Machine Learning, Automated Suspicion Algorithms, and the Fourth Amendment. University of Pennsylvania Law Review, (164), 871-930.

Sánchez, E. G. (2019). La Patentabilidad de la Inteligencia Artificial. Compatibilidad con otros sistemas de protección. La Ley mercantil, (59), 4.

Thaler, v Iancu et al (1:20-cv-00903). Court Listener. In the United States District Court for the Eastern District of Virginia, 2020. Recovered from https://storage.courtlistener.com/recap/gov.u scourts.vaed.483404/gov.uscourts.vaed.4834 04.1.0.pdf.

The European Patent Convention. (1973). European Patent Office. Recovered from https://documents.epo.org/projects/babylon/e ponet.nsf/0/53A0FE62C259803BC12586A9 
0058BCAD/\$File/EPC_17th_edition_2020_ en.pdf.

Tull, S., \& Miller, P. (2018). Patenting Artificial Intelligence: Issues of Obviousness, Inventorship, and Patent Eligibility. The Journal of Robotics, Artificial Intelligence \& Law, 1(5), 313-325.

UK Intellectual Property Office. (2019). Patent Decision BL O/741/19 of 4 December 2019. Recovered from https://www.ipo.gov.uk/pchallenge-decision-results/o74119.pdf.
United States Patent and Trademark Office. USPTO. (2019). «Petition decision: Inventorship limited to natural persons». Recovered from https://www.uspto.gov/sites/default/files/doc uments/16524350_22apr2020.pdf?utm_cam paign=subscriptioncenter\&utm_content $=\& u t$ m_medium=email\&utm_name=\&utm_sourc e=govdelivery\&utm_term $=$.

Vertinsky, L. (2017). Thinking Machines and Patent Law. Emory Legal Studies Research Paper, (1), 1-23. 